\title{
HOE DIREK LEI DIE GEES? \\ 'N DOGMATIESE EN EKSEGETIESE ONDERSOEK RONDOM ROMEINE 8:14
}

\section{W. NICOL}

In Rom. 8:14 en Gal. 5:18 sê Paulus dat die Gees die gelowige t.o.v. sy praktiese lewe lei. Hy verduidelik nie eksplisiet hoe die gelowige dié leiding ontvang nie. Daar is aspekte van die saak waaroor daar onder ons nie onsekerheid bestaan of hoef te bestaan nie. Dit is duidelik dat die basiese middel waardeur die Gees lei die Woord is, d.w.s. die boodskap van die koninkryk. Dié boodskap is die woord van God met 'n duidelike "uitwerking" op dié wat dit glo (1 Tess. 2:13), waardeur die Gees beheer kry oor hulle lewens en hulle lei om God se wil te ken en te doen. Dit word hier as basis aanvaar, en die vraag waarop ons ons toespits is of die Gees in sy leiding ook meer direk te werk gaan. Die doel van hierdie artikel is om die vraag in dogmatiese kader te plaas, eksegeties na te vors, en dan konklusies te trek.

Die populêre opvattings oor die saak in ons kerk bevat teenstrydighede. Dit kom nie algemeen voor dat lidmate oor 'n sekere besluit wat hulle geneem het, sê dat die Here hulle so gelei het nie. So 'n uitspraak sou maklik as sektaries beleef kon word. Die praktyk van die lede van die Morele Herbewapening om vroeg soggens ' $n$ tyd van stilte opsy te sit om te luister vir leiding en dit op te teken, word oor die algemeen onder ons afgekeur. Maar ons maak twee uitsonderings waar ons oor die algemeen verkies dat ' $n$ persoon sê hy is gelei in sy besluit: wanneer 'n persoon besluit dat hy predikant wil word, en wanneer 'n predikant oor ' $n$ beroep beslis. Miskien kan 'n mens sê dat dit hier volgens die populêre opvattings onder ons oor die pieke van die religieuse ervaring gaan: die predikant is die persoon naaste aan God, veral wanneer dit oor sy grootste besluite gaan. Maar so wil ons tog nie dink nie, want ons is mos gereformeerd, ook in ons verwerping van alle vorme van klerikalisme. Populêre opvattings onder ons kom dus daarop neer dat daar soms na direkte leiding gesoek mag word, en soms nie. Dit is onaanvaarbaar, en ons moet hier kyk of ons dié probleem kan oplos.

\section{DIE DOGMATIESE KADER}

Elke gereformeerde behoort 'n diep huiwering in hom te voel opkom 
wanneer daar gepraat word oor die moontlikheid van 'n direkte werksaamheid van die Gees, d.w.s. 'n werksaamheid wat nie tot sy werking deur die Woord beperk is nie. Sodra ons op ons teologiese geskiedenis terugkyk, word dit verstaanbaar dat hierdie huiwering inderdaad baie diep is, omdat die kerk van die begin af met mense te doen gehad het wat geglo het dat hulle direkte kontak met die Gees het en in dwaalleer verval het.

Hier onder sal ons daarop ingaan dat reeds Paulus in sy eerste Korintebrief teen 'n naiewe geloof in die direkte werksaamheid van die Gees moes stry.

Van heel vroeg af is die kerk bedreig deur die gevaar van mistiek waarin daar na' $n$ onpersoonlike eenwording met God gestreef is. Mistiek neig steeds daartoe om alle vorme van bemiddeling tussen die mens en God te verwerp, sodat mistici die kerk en die Woord oorbodig verklaar in die eenwordingsproses. Die mistiek in die kerk is deur die NeoPlatonisme beïnvloed waarvolgens die siele van die mense wesenlik emanasies van die ewige gees is, wat daarop neerkom dat elke mens iets van God in hom het. Hiervolgens sou die materie duisternis wees, en die hooftaak van die siel om hom daarvan los te maak en terug te keer na die ewige gees om daarmee verenig te word. Die neiging wat hiermee saamhang, is dan om alle uiterlike dinge soos die kerk en die woord as materie te sien, en te degradeer. ${ }^{1}$ ' Dit is duidelik dat egte mistiek heidense wortels het en dat daar ' $n$ baie diep verset daarteen in die kerk moes groei.

Die mistiek het meer invloed op die Oosterse as die Westerse kerk uitgeoefen. E.g. het dit so begin sien dat daar twee weë tot die Vader is, $\mathrm{nl}$. die Seun en die Gees. Die weg deur die Gees is gevolglik van die Woord losgemaak, sodat daar ruimte gekom het vir die idee van die direkte inwendige lig van die Gees en dus in ongesonde mistiek. ${ }^{2}$ ' Hierdie ontkoppeling van Seun of Gees het ook daartoe gelei dat hulle alles wat 'n geestelike of kulturele karakter dra, kon sien as die werk van die Gees waardeur die goddelike geheim onthul word. ${ }^{3 \text { ' }}$ Daarteenoor het die Westerse kerk aan die noue band tussen Seun en Gees vasgehou: die Gees werk nie los van die Seun en die Woord nie, maar dra die heilswerk in ons lewens in. Dat die kerk toe in $1054 \mathrm{nC}$ geskeur het oor die vraag of die Gees van Vader en Seun (filioque) uitgaan, het dus baie diep wortels gehad wat waarskynlik tot vandag toe die weerstand in ons kollektiewe bewussyn teen 'n ontkoppeling van die Gees versterk.

In die beklemtoning van die direktheid van die Gees se werk, het verskeie ander bewegings wat aan die rand van die kerk geleef het met die mistiek ooreengestem. In die moderne geskiedskrywing word hulle spiritualiste genoem." Ons dink hier aan die geesdrywers, die entoe- 
siaste, die religieuse subjektiviste en die beoefenaars van die "innerlike woord".

Reeds in die tweede eeu was een van die grootste gevare die Montanisme, en Montanus was 'n geesdrywer wat hom as profeet voorgedoen het. Telkens het die geesdrywers hulle daarop beroep dat hulle direkte openbaringe en leiding van die Gees ontvang het, en so hulle dwaalleer probeer regverdig. In die tyd van die Reformasie het die Anabaptiste en hulle entoesiastiese geesgenote vir die kerk gedugte opposisie gelewer.

Een van die insiggewende verskyningsvorms van spiritualistiese subjektivisme is die Kwakers. Hulle stigter, George Fox, het 'n stem uit die hemel gehoor, en in dié beweging word daar meer gesag aan die innerlike woord as aan die Bybel toegeken. Hulle glo dat daar in elke mens iets van God is, en dat Christus elkeen heel spesifiek lei. Daarom is "silent worship" en "centering in yourself" belangrik. 'n Mens is nie verras om in hierdie klimaat 'n anti-institutêre ekklesiologie aan te tref nie. Die uiterlike organisasie van die groep word sover as moontlik beperk en daar is geen ampte nie. ${ }^{5)}$

Tussen die Kwakers, die Keswick-beweging, die Morele Herbewapening en Andrew Murray jr. bestaan daar sekere raakpunte. Die Keswick-beweging wat sedert die vorige eeu in die Britse Protestantisme gebloei het, het stil gebed beklemtoon en die Gees op so 'n wyse as leier gesien dat hulle nie formele verkiesings van leiers wou hou nie. ${ }^{6}$ ) Frank Buchman, die stigter van die Oxford-groep wat later in die Morele Herbewapening ontwikkel het, het a.g.v. kontak met die Keswickbeweging tot bekering gekom. ${ }^{71} \mathrm{Hy}$ skryf self dat hy elke dag tussen 05h00 en 06h00 opsy sit "to listen to the still, small Voice to inspire and direct. God told me what to do and I wrote it down". ${ }^{8}$ )

Andrew Murray jr. het tydens sy studiejare invloed van die Réveilbeweging in Nederland ondergaan wat tot mistiek geneig het en later noue kontak met die Keswick-beweging onderhou. In samehang hiermee het hy 'n taamlike openheid vir mistiek gehad. Hy het bv vir William Law, die bekende Engelse mistikus van die $18 \mathrm{e}$ eeu, bewonder, en ses boeke met aanhalings uit sy werke uitgegee. Daarbenewens het hy ook verskeie ander mistici intensief gelees. Law was skriftuurliker as baie ander mistici, maar het tog panteïstiese trekke vertoon en t.o.v. die openbaringsleer, die versoeningsleer en die ekklesiologie van die suiwer pad afgewyk. Andrew Murray het sy beswaar teen Law uitgespel, maar dit is veels te flou, $\mathrm{nl}$ dat Law die innerlike van die verlossing te veel beklemtoon. ${ }^{9}$ ' Wanneer ' $n$ mens in die werke van Murray self begin soek na die verwante dwalings, vind jy nie wat jy verwag het nie. Hy poneer dat God ons deur die hele dag lei as ons daarop wag, maar formuleer 
steeds heel versigtig, sodat ons nie kan sê dat hy die Gees in bepaalde metodes probeer vang of die heerskappy van die Heilige Skrif in gevaar stel nie. ${ }^{101}$

Hiermee het ons tot naby aan ons eie geestelike situasie gekom, en onsself opgeskerp om teen vreemde strominge te waak in ons besinning oor die moontlike direkte werksaamheid van die Gees.

Ons kyk nou eers na hoe daar in ons eie Reformatoriese en gereformeerde tradisie op die spiritualisme geantwoord is.

Martin Luther het in sy jeug invloed van die mistiek ondergaan, en aanvanklik die gedagte van die inwendige woord waardeur die Gees direk in die hart van die gelowige getuig, aangeneem. Toe hy later die gevare van hierdie gedagte ondervind het deur die probleme wat hy met die geesdrywers gehad het, het hy baie sterk standpunt ingeneem teen alle vorme van spiritualisme en beklemtoon dat die Gees nooit sonder die Woord werk nie. Een van sy bekende uitsprake was: Deus interna non dat nisi per externa (God gee nie die innerlike dinge anders as deur die uiterlike dinge nie). Die latere Lutherane het hierdie standpunt nog onverbiddeliker gehandhaaf en beklemtoon dat die Gees slegs per verbum werk. ${ }^{11}$ ' Dit het teenoor die standpunt van die Calvinistiese Ortodoksie gestaan dat die Gees cum verbo werk - 'n standpunt wat die Gees nie volledig aan die Woord gebind het nie. Die Lutherse standpunt skep teologiese probleme. As die Gees so volledig aan die Woord gebind word, ontstaan die vraag of die Gees nie 'n gevangene van die Woord word en of die Woord nie outomaties met 'n byna magiese krag werk nie. Die probleem is dan waarom die Woord nie sy hoorders altyd tot geloof beweeg nie. Om dié probleem op te los, het die Lutherane die beslissing dikwels in die vrye wil van die hoorder laat setel en so in sunergisme beland. ${ }^{12)}$

Die ander reformatore het nie so ver soos Luther gegaan nie. Zwingli en selfs Bucer het geleer dat die Woord nie altyd noodsaaklik is vir die werking van die Gees nie. ${ }^{131}$

Calvyn het oor die algemeen sterk standpunt teen die spiritualisme ingeneem, en beklemtoon dat die Gees nie van die Woord losgemaak mag word nie. Teenoor die Libertyne verwerp hy die idee van direkte toegang tot die Gees, en stel met verwysing na Joh 16:13 dat die Gees geen nuwe leerstellings vir ons gee nie, maar die inhoud van die Woord in ons gedagtes bring. 14) Hy kan sonder meer sê: "The Word is the instrument by which the Lord dispenses the illumination of his Spirit to believers."15)

Tog skep hy duidelik meer ruimte vir die werk van die Gees as Luther. Oor die algemeen benadruk hy baie sterk dat dit die Gees is wat die heil in Christus ons eie maak. Die titel van die eerste hoofstuk van die derde boek van die Institusie is: "The things spoken concerning Christ 
profit us by the secret working of the Spirit." Hy sê: "Until our minds become intent upon the Spirit, Christ, so to speak, lies idle because we coldly contemplate Him as outside ourselves." Die Gees is "the inner teacher by whose effort the promise of salvation penetrates our minds." ${ }^{16)}$ Ons kan die Woord nie sonder die verligting van die Gees verstaan nie: sonder Hom is ons blind vir die bedoeling van die Woord, maar Hy gee ons "insight into the treasures of heaven." ${ }^{17)}$ Vanweë die groot rol wat hierdie oortuigings by hom speel, is hy al die teoloog van die Heilige Gees genoem.

Dit was dan ook Calvyn wat die leer van die testimonium Spiritus Sancti internum ontwikkel het. T.o.v. die vraag hoe ons van die goddelike gesag van die Skrif oortuig kan wees, het hy gesê dat rasionele argumente ' $n$ sekere waarde kan hê, maar dat ons die volle oortuiging slegs uit "the secret testimony of the Spirit", deur sy "inward testimony" kan ontvang. Die vraag kan gestel word of hy bloot na die geestelike oortuigingskrag van die boodskap van die Woord verwys, of bedoel dat die getuienis van die Gees ' $n$ addisionele werking is. $\mathrm{Lg}$ is klaarblyklik die geval. Met verwysing na die Skrif sê hy bv: "For even if it wins reverence for itself by its own majesty, it seriously affects us only when it is sealed upon our hearts through the Spirit."18) Hy bedoel werklik ' $n$ addisionele innerlike werksaamheid van die Gees wat nie van die uiterlike hoor van die Woord losgemaak kan word nie, maar ook nie daarin opgaan nie. Hierdie element van die addisionele hou natuurlik sekere gevare in wat bv in die Gereformeerde Piëtisme van die 16e en 17e eeu uitgekom het insoverre hulle dit oorbeklemtoon het dat 'n mens op innerlike gebeurtenisse moet wag en sodoende ongesonde introversie en geloofsonsekerheid veroorsaak het. Maar as ons nie aan hierdie element van die addisionele vashou nie, verval ons weer in die Lutherse outomatisme. Dit is ook duidelik dat art. 5 van die Nederlandse Geloofsbelydenis nie vir hierdie element terugskrik nie. Dit sê dat ons alles in die boeke van die Bybel glo "nie juis omdat die kerk hulle aanvaar en as sodanig beskou nie, maar veral omdat die Heilige Gees in ons hart getuig dat hulle van God is." Dat Calvyn aan die ander kant glad nie 'n getuienis los van die Skrif bedoel nie, is sonder meer duidelik. Die uitsluitlike uitwerking van die getuienis is dat ons die inhoud van die Skrif glo, maar die getuienis is wel 'n bykomstige, innerlike en in dié sin direkte werking van die Gees. ${ }^{19}$ )

Hiermee hang dit saam dat Calvyn op ander gebiede ruimte laat vir 'n meer direkte werksaamheid van die Gees, solank dit net duidelik blyk dat dit nie oor nuwe openbaringe gaan nie. Veral in sy verdediging van die kinderdoop maak hy die uitsondering dat die Gees ook sonder die Woord kan werk. ${ }^{20)}$ Hy sê die oortuiging dat 'n mens predikant moet 
word, kom as ' $n$ geheime innerlike roeping waarvan ' $n$ mens self voor God bewus is. ${ }^{21}$ ' Wanneer hy oor gebed handel, sê hy dat ons hulp nodig het, en daarom gee God ons die Gees "as our teacher in prayer, to tell us what is right and temper our emotions ... He arouses in us assurance, desires and sighs, to conceive which our natural powers would scarcely suffice". ${ }^{22)}$ T.o.v. die lewe van die gelowige deins hy bv nie vir die volgende woorde terug nie: "For by the inspiration of his power he so breathes divine life into us that we are no longer actuated by ourselves, but are ruled by his action and prompting" (sed eius actione ac mota regamur). ${ }^{23)}$

Ten slotte net enkele flitse uit ons eie gereformeerde voorgeskiedenis. In die tyd van die Gereformeerde Ortodoksie het die leer van die testimonium Spiritus Sancti internum veld verloor omdat hulle a.g.v. die rasionalisme die gesag van die Skrif met die rede probeer bewys het, maar dit is duidelik dat dit nie eg gereformeerd was nie. Daarteenoor was daar in die Afskeiding in Nederland (1834) heelwat subjektivisme, maar daar is volhardend daarteen gestry sodat die Gereformeerde Kerke in Nederland uiteindelik in ' $n$ nie-piëtistiese Kerk ontwikkel het. ${ }^{24)} A$. Kuyper het egter nog meer ruimte vir die onmiddellike werking van die Gees gemaak as Calvyn. Hy het byvoorbeeld geleer dat die Gees die wedergeboorte sonder die Woord bewerk en die Woord in 'n mate op die agtergrond gestel. H. Bavinck het weer digter by Calvyn se standpunt gebly, $\mathrm{nl}$ dat die Gees in die reël deur die Woord werk. ${ }^{25)}$ Dit is ' $\mathrm{n}$ vraag of hierdie gereformeerde standpunt dat die Gees saam met die Woord werk, maar by wyse van uitsondering ook daarsonder, heeltemal bevredigend is.

\section{EKSEGETIESE ONDERSOEK}

Die eenstemmige getuienis van die Nuwe Testament kom daarop neer dat die Gees nie 'n driehoek met die Vader en Seun vorm nie, maar as't ware op die een lyn lê wat van die Vader deur die Seun na ons loop. Op grond van die kruis en opstanding stuur die Vader en Seun Hom vir ons om ons die weldade van Christus deelagtig te maak. Wat in die Ou Testament oor die Gees geopenbaar word, is voorlopig. Daar is dus goeie rede om ons in die eksegetiese ondersoek tot die Nuwe Testament te beperk.

Die Nuwe Testament bevat heelwat gegewens oor die onmiddellike of direkte werk van die Gees. Waar dit oor die inspirasie van die Skrif handel (byvoorbeeld 2 Tim. 3:16; 2 Pet. 1:20-21), is die gedagte van 'n afgeslote werksaamheid duidelik teenwoordig, maar die res van die gedeeltes wil klaarblyklik aan die hele kerk leiding gee. 
Uit Matteus kan 10:19-20 hier sonder verduideliking gesiteer word: wanneer Christene aangekla word, "moet julle julle nie bekommer oor hoe of wat julle moet sê nie, want op daardie oomblik sal God aan julle gee wat julle moet sê. Dan is dit nie julle wat praat nie, maar die Gees van julle Vader wat deur julle praat".

In Johannes bevat die afskeidsredes sterk uitsprake oor die leiding, lering en getuienis van die Gees (14:25-26; 16:12-15; 15:26-27; $16: 8-11)$. Met die oog op ons spesifieke vraagstelling is hierdie verse nie van direkte belang nie, omdat dit hier om die Gees se werk t.o.v. die openbaring van Christus, d.w.s. die Woord handel. Sy leerarbeid behels die dieper insig in die betekenis van die openbaring, en sy getuienis inspireer die getuienis van die gelowiges aangaande die openbaring. Dit bly die basis waarop ons ons vraagstuk moet hanteer.

Lukas maak in sy twee boeke veel meer van die Gees as Matteus en Markus. Sy beskouings oor die Gees word deur ' $n$ mate van verskeidenheid gekenmerk, sodat dit nie maklik is om te bepaal hoe die verskillende motiewe gekombineer moet word nie. Hier kyk ons slegs vlugtig na wat vir ons vraagstuk van belang is, sodat ons meer aandag aan Paulus kan wy. In Lukas se geskrifte word die werk van die Gees dikwels deur die uitsonderlike gekenmerk, maar hy verleen tog ook ' $n$ breër basis aan die saak. Die Gees is die gawe van God aan almal wat in Jesus glo (Hand. $2: 38$. Sy teenwoordigheid word nie net geglo nie, maar ook aan sy duidelike werksaamheid ervaar, sodat daar aan gelowiges gevra kan word of hulle Hom reeds ontvang het of nie (Hand. 19:2). Hy bewerk nie net uitsonderlike kwaliteite nie, maar ook wysheid (Hand. 6:3) en blydskap (Hand. 13:52). Sy primêre werksaamheid in die individuele gelowige is die gawe van profesie. ${ }^{26)}$ Die ideaal is dat alle gemeentelede die profetiese gawe moet beoefen. Die profetiese spreke word as ' $n$ bonatuurlike geinspireerde getuienis gesien wat byvoorbeeld selfs in tale gelewer kan word wat natuurlikerwys aan die sprekers onbekend is (Hand. 2:6), en die toekoms kan onthul (byvoorbeeld 11:28). Lukas stel dit dikwels so voor dat die Gees die toekoms aan gelowiges openbaar: Luk. 1:41 e.v.; 1:67; 2:26; Hand. 11:28; 20:23; 21:4,11. Die Gees stel Paulus ook in staat om ' $n$ ander man se verborge motiewe deur te sien (Hand. 13:9). Die Gees gee ook telkens insig in God se verborge wil, sodat die mense direkte leiding t.o.v. hulle konkrete handele van Hom ontvang. Filippus word na 'n eensame pad gestuur (Hand. 8:29); Petrus kry die opdrag om nie te huiwer om by ' $n$ onbesnedene tuis te gaan nie (Hand. 10:19-20; 11:12); vir die gemeente sê die Gees om die eerste sendingreis te beplan (Hand. 13:2,4); die sendelinge word verhinder om sekere streke te besoek (Hand. 16:6-7) en Paulus word gedring om na Jerusalem toe te gaan (Hand. 20:22). Hy lei so duidelik oor wat gedoen 
moet word dat daar geen teenspraak moontlik is nie.

Paulus gaan nog verder as Lukas om 'n breë teologiese basis aan sy beskouings oor die Gees te verleen. Sy uitsprake oor die Gees kom dikwels in die vorm van duidelike opdragte aan gewone gelowiges, sodat ons geen twyfel kan hê dat ons daaraan gehoorsaam moet wees nie. Dit is nie eenvoudig om vas te stel wat hy presies met die leiding van die Gees bedoel nie, maar so 'n ondersoek sal ons baie help met ons vraagstuk.

Daar bestaan ingrypende verskille tussen eksegete t.o.v. die Pauliniese "pneumatologie". 27) Vir ons doel hier is die beste toegang om ons nie by die hele debat te laat betrek nie, maar om net te vra na die verhouding tussen die Gees en wonderkrag by Paulus. In 1888 in sy beroemde eerstelingsgeskrif het Hermann Gunkel die oë van die teologiese wêreld daarvoor geopen dat die idealistiese verstaan van die Gees verkeerd is, en dat die oer-christendom die Gees o.a. as die krag van die wonder en ekstase verstaan het. Dit is duidelik dat Paulus die Gees ook in ' $n$ breër sin as die gewer van die nuwe lewe verstaan, en die vraag is in watter verhouding die opvatting van die Gees as wonderkrag tot hierdie breër gedagte staan.

Daar kan ten minste drie verskillende wyses waarop ondersoekers die saak hanteer, onderskei word:

\section{Die aanduidings dat Paulus die Gees ook aan wonderkrag koppel, word min of meer geignoreer}

So 'n hantering van Paulus kom algemeen in die gevestigde kerke voor, en die rede lê natuurlik daarin dat eksegete neig om uitsprake oor die Gees in terme van hulle kerk se wêreldbeeld en ervaring van die Gees te verstaan. As voorbeeld noem ek hier slegs die uitgebreide en deeglike Paulus-interpretasie van Herman Ridderbos ${ }^{281}$ wat die nuwe lewe as "leven door de Geest" beskrywe en aandag aan die verskillende charismata wy, maar die aspek van die wonder en ekstase nêrens in die pneumatologie in berekening bring nie.

Dit moet dadelik vir ons duidelik wees dat ons hierdie aspek nie kan ignoreer nie. In Gal. 1:16 sê Paulus self dat sy bekering daarop gegrond was dat God sy Seun aan hom geopenbaar het (apokaluptein). Hy ken geestesverrukking, want in 2 Kor. $12: 1-5$ sê hy dat hy wel bereid is om te roem oor die gesigte en openbarings (apokalupseis) wat hy ontvang het, o.a. toe hy tot in die derde hemel weggeruk is. Die Korintiërs se gebruik van vreemde tale in die erediens het in ' $n$ geesdrywery ontaard, sodat Paulus dit moes beperk, en tog stel hy dit aan hulle dat hy persoonlik meer van vreemde tale gebruik maak as hulle almal (1 Kor. 14:18) 
en waarsku hy hulle teen die einde van sy betoog om nie die gebrulk van vreemde tale te verhinder nie (1 Kor. 14:39). Dit is nie Paulus se mening dat die ontvang van openbaringe iets uitsonderliks moet wees wat net tot 'n klein groepie beperk moet bly nie. Hy moedig die gemeente aan dat hulle almal daarna moet streef om die gawe van profesie te ontvang 11 Kor. $14: 1,5,12,39)$. Hy sien die profete in die gemeentes as persone aan wie inhoude geopenbaar word (apokaluptesthai) 1 Kor. 14:30, vergelyk 14:26), so direk dat hulle soms nouliks kan wag om dit bekend te maak (14:30). Die profete het dus nie die tradisie oorgedra soos die leraars nie, maar openbaringe bekendgemaak. ${ }^{29}$ ) Paulus se eie verkondiging berus nie net gedeeltelik op die openbaringe wat hy self ontvang het nie, maar gaan ook gepaard met die tekens van die Gees se werk. Sy verkondiging was "met woord en daad, deur kragtige tekens en wonders, in die krag van die Gees van God" (Rom. 15:19, ook 2 Kor. 12:12). Hy herinner die Galasiërs daaraan dat God aan hulle by hulle bekering die Gees gegee het gepaardgaande met kragte (dunameis) wat $\mathrm{Hy}$ onder hulle gewerk (energon) het (Gal. 3:5). In 1 Kor. 12:10 dui dieselfde woorde op charismatiese kragte).

Hierdie gegewens is nie negeerbaar nie. Ons sal hierdie element in Paulus se pneumatologie moet erken, en moet vra in watter verhouding dit tot die ander elemente staan.

2. Die element van wonderkrag in die Pauliniese pneumatologie word erken, maar as 'n tradisionele res beskou wat hy wesenlik in sy eie ontwikkeling van die pneumatologie oorwin

In hierdie eeu was dit veral Rudolf Bultmann wat hierdie beskouing wyd uitgedra het. ${ }^{30)} \mathrm{Hy}$ sê die oergemeente verstaan die Gees in die Joodse tradisie as die gawe van die eindtyd wat profesie en wonders bewerk. ${ }^{311}$ Die hellenistiese gemeentes sou hierdie beskouing basies behou het, en daarby gevoeg het dat elke gelowige die Gees by die doop ontvang, sodat sy hele lewe deur Hom bepaal word. Op dié wyse sou daar 'n spanning ontstaan het tussen twee strydige beskouings, $\mathrm{nl}$ die Gees as wondermag en as lewenskrag. ${ }^{32)}$ Paulus sou hierdie populêre beskouings wesenlik oorgeneem het, sodat sy pneumatologie ook deur ' $n$ dubbelheid gekenmerk is. As Bultmann Paulus se eintlike bedoeling egter moet interpreteer, beweeg hy weg van die gedagte van konkrete wonderkrag, en sien hy die Gees van Paulus in lyn met sy eksistensiale Skrifuitleg "nicht als mysteriöse ... Kraft ..., sondern als die neue Möglichkeit echt geschichtlichen Lebens". ${ }^{33)}$

Baie eksegete het hulle by hierdie beskouingswyse aangesluit. Eduard Schweizer het benadruk dat die Gees by Paulus nie werklik deur 
uitsonderlike werkinge gekarakteriseer word nie, maar as die Gewer van die geloof en die geloofslewe. ${ }^{34)}$ Ingo Hermann voer die saak 'n bietjie verder deur te sê dat Paulus die idee van die Gees as wondermag in wese "überwindet" deur die konsep dat $\mathrm{Hy}$ die draer van die nuwe lewe is. ${ }^{35}$ ) In sy dissertasie oor Paulus se pneumatologie, het JS Vos tot die konklusie gekom dat die ekstatiese en wonderlike nie werklik deel van Paulus se pneumatologie vorm nie. ${ }^{361}$

'n Ondersoeker met 'n soortgelyke kyk op Paulus se Geesbegrip sal neig om die leiding van die Gees sterk in die denkprosesse van die gelowige te integreer.

3. Die wonder-aspek van die Gees se werk word as 'n bepalende element in die Pauliniese pneumatologie beskou en daarin geïtegreer

Bultmann se kritiese leerling, Ernst Käsemann, het sy leermeester se opvatting omgekeer. Waar Bultmann die Gees aan die individuele eksistensie koppel, sien Käsemann Hom kosmologies: $\mathrm{Hy}$ is die magsgreep van die opgestane Kurios na die aarde. Die wonder-like het blykbaar algaande ' $n$ groter rol in sy verstaan van die Gees by Paulus gespeel. In 1958 sien hy die ekstatiese nog slegs as deel van Paulus se pneumatologie. ${ }^{37}$ ) In 1969 stel hy: "Dabei darf nicht übersehen werden, dass Paulus auch seinerseits von den Voraussetzungen des hellenistischen Enthusiasmus ausgeht" (ek kursiveer, WN). ${ }^{38)}$ In sy Romeine-kommentaar van 1973 formuleer hy nog sterker. ${ }^{39)} \mathrm{Hy}$ sê Paulus beskou die Gees as ' $n$ vreemde mag, en daarom moet die leiding van die Gees in Rom. 8:14 as 'n gedryf-word deur die Gees verstaan word. Dit moet nie tot "gelei word" verswak word om die vrye sedelike beslissing van die mens in te sluit nie. Selfs t.o.v. ons handele hou Paulus die extra nos van die genade vas, want alleen daardeur word die moontlikheid van oorwinning verseker. Die menslike lewe is ' $n$ strydtoneel waarin die mens self nie kan beslis nie. Slegs as ons pneumatologie nie bang is om van "hingerissen werden" te praat nie, is dit werklik die keersy van die regverdiging van die goddelose; die vreemde geregtigheid korreleer met die vreemdheid van die Gees se mag.

Om 'n eie weg te soek, moet ons allereers daarop let dat Paulus sy pneumatologie beslis nie deur die ekstatiese Geesdrywers van sy tyd laat bepaal nie. Hy span eerder verskeie motiewe in sy briewe in om die geesdrywery te beperk. Een van die gevare van die ekstatiese Geeservaring was dat dit die gemeente verdeel en afbreek soos wat in Korinte gebeur het. In sy eerste brief aan hulle benadruk Paulus dat die Gees die verskillende charismata gee met die doel om die gemeente op te bou 11 Kor. 
12 en 14). Dit is duidelik dat Paulus hiermee bedoel om die ekstatiese aspek van die Korintiërs se Geeservaring t.w.v. die eenheid, orde en liefde in die gemeente in te perk. ' $n$ Volgende motief waardeur Paulus die ekstatiese neigings in die hellenistiese gemeentes teengaan, is dat hy beklemtoon. Die derde motief waardeur Paulus die geesdrywery probeer dat $\mathrm{Hy}$ nog net die pand of waarborg, die voorloper van die eskatologiese heerlikheid is (vergelyk Ef. 1:14). Die Korintiërs moet hulle dus nie in hulle entoesiasme verbeel dat hulle reeds uit die dood opgestaan het nie, maar aanvaar dat hulle nog in 'n gebroke wêreld lewe waarin die Gees hulle in staat stel om mekaar te verdra en lief te hê. Daarom staan die behandeling van die liefde in 1 Kor. 13 tussen die twee hoofstukke wat die charismata behandel, en word verdraagsaamheid daarin herhaaldelik beklemtoon. Die derde motief waardeur Paulus die Geesdrywery probeer bekamp is dat hy die Gees onlosmaaklik aan Christus verbind. Die Gees is nie 'n mag wat van Christus los staan en wat die ekstatici op enige vreemde en nuwe manier kan beleef nie, maar Paulus teken dit deurgaans so dat die Gees die wyse is waardeur die boodskap en teenwoordigheid van Christus magtig tot ons kom. ${ }^{40}$ )

Die aspek van die wonder is nie dominant in Paulus se pneumatologie in die sin dat dit die ander aspekte verdring nie. Die drie bogenoemde motiewe maak dit moontlik dat Paulus dit kan benadruk dat die Gees nie net gawes skenk nie, maar ook die vrugte van die heiligmaking in die gelowiges bewerk, waarvan die liefde met sy nugterheid en realisme (vergelyk 1 Kor. 7) die eerste is.

Nadat ons dit alles erken het, moet ons tog ook sien dat die aspek van die wonder 'n wesenlike deel van Paulus se Geesbegrip uitmaak. Ons moet besef dat dit vir mense soos ons wat aan nie-charismatiese kerke behoort moeilik is om hierdie aspek raak te sien, omdat die Gees in ons kringe normaalweg nie so ervaar word nie. Indien ons hierdie aspek wel sien, is ons vanweë ons agtergrond geneig om 'n spanning tussen die wonderlike en "gewone" werk van die Gees te veronderstel. Ons projekteer die spanning tussen die charismatiese en nie-charismatiese kerke in Paulus. As 'n mens dit doen, laat jy die wonderlike en "gewone" werk van die Gees met mekaar kompeteer, en sal jy neig om die een die oorhand te laat kry. Die briewe van Paulus is egter vol tekens dat die wonder-aspek nie vir hom in spanning met die res van sy pneumatologie staan nie, maar ' $n$ integrale eenheid daarmee vorm. ${ }^{411}$

Die wonderkrag van die Gees kom duidelik tot uiting in die charismata, en dit bly opvallend dat Paulus "gewone" en "wonderlike" charismata so deurmekaar kan noem (1 Kor. 12:7-11; Rom. 12:6-8). Vir ons gevoel bestaan daar ' $n$ kwalitatiewe verskil tussen ' $n$ woord van wysheid en 'n vreemde taal, maar Paulus toon geen teken dat hy so 'n onderskeid 
aanvoel nie.

In Paulus se beskrywing van sy eie verkondiging is die wonderlike ook goed geïntegreer. Hy sê dat Christus t.o.v. sy sendingwerk "met woord en daad" deur hom gewerk het om die heidene tot geloof te bring (Rom. 15:18). Die "daad" verwys na die "kragtige tekens en wonders" van die Gees (vers 19), en die woord wat daarmee 'n eenheid vorm, bevat Paulus se verstandige en logiese aanbieding van die heilsboodskap. Sy "gewone" verkondiging is in sy oë net so wonderlik as die wonders wat plaasgevind het. Om dit te verstaan, moet ons veral na 1 Kor. 2 kyk. Sy boodskap is oortuigend, nie vanweë "geleerdheid en welsprekendheid" nie, maar vanweë "die betoning van Gees en krag" (4). Dit verduidelik hy deur te sê dat die inhoud van sy boodskap nooit deur mense bedink kon word nie, maar deur die Gees aan hom geopenbaar is $(9-10)$ en dat hy dit verkondig "met woorde wat die Gees ons leer". Dit is onseker of die "krag" van vers 4 mede na wonderwerke verwys, maar daar kan geen twyfel bestaan dat dit ten minste na die krag van die geïnspireerde verkondiging verwys nie. Die woord "krag" (dunamis) kan dus in die verband van die verkondiging in Rom. 15:19 en 1 Kor. 2:4 na die krag van sowel die woord as die wonderwerk verwys. 1 Kor. 2 benadruk dat Paulus se bekering vir hom nie ' $n$ geïsoleerde ervaring was nie, maar dat die openbaring van die Seun wat hy daar ontvang het vir hom die basis van sy verkondiging was. In Gal. 1:16 stel hy dit dan ook dat God sy Seun aan hom geopenbaar het "sodat ek die evangelie oor Hom onder die heidennasies sou verkondig".

In hierdie lig kan ons die rol van die Gees in gebed verstaan soos dit in Rom. 8 en Gal. 4 na vore kom. Volgens Rom. 8:15 stel die Gees ons in staat om "Abba" te roep, en volgens Gal. 4:6 roep Hy dit in ons. Daar bestaan onsekerheid of hierdie roep kulties, persoonlik of ekstaties opgevat moet word, maar dit is wel duidelik dat hier van 'n direkte werksaamheid van die Gees sprake is. Hy werk nie bloot onmerkbaar op ons in sodat ons kan roep nie, maar $\mathrm{Hy}$ is so direk by die roep betrokke dat Paulus kan sê Hy roep. Hierdie roep styg op uit die hart van hom wat deur die mag van die Gees oorweldig is. ${ }^{42)}$ In albei hoofstukke is dit duidelik dat hierdie aspek van die Gees se werk nie ' $n$ tradisionele res in Paulus se briewe is nie, maar diep in sy sentrale gedagtes oor Christus en die Gees geïntegreer. In Galasiërs is die Abba-roep aan een van die sentrale gedagtes van die brief verbind: Christus het ons losgekoop van slawerny aan die wet sodat ons as kinders van God aangeneem kan word, en die Gees bevestig dit deur God in ons as Vader aan te roep. In die verse rondom Rom. 8:15 is die kinders van God 'n sentrale tema: dit is hulle wat die sonde oorwin en erfgename van die eskatologiese heerlikheid is. Ons kan sekerheid hê dat dit op ons van toepassing is, 
want "die Gees getuig aan ons gees dat ons kinders van God is" (16). Die Abba-roep wat die Gees in ons oproep, dien as ' $n$ verdere bevestiging hiervan.

In noue verband hiermee staan die intrede van die Gees t.o.v. ons gebede wat in Rom. 8:26-27 genoem word. Die Gees doen vir ons wat ons nie kan doen nie: "ons weet nie wat en hoe ons behoort te bid nie, maar die Gees self pleit vir ons met onuitspreeklike versugtinge". Oor die algemeen is die eksegete dit daaroor eens dat dit nie oor 'n werksaamheid van die Gees in die hemel gaan nie, maar in ons. ${ }^{43)}$ Dit is onseker of die "onuitspreeklike versugtinge" na glossolalie verwys"4) of nie, maar die wonder-like van hierdie werksaamheid van die Gees is in elk geval daarin geleë dat die Gees iets doen wat ons nie kan doen nie; Hy versterk nie bloot ons eie vermoëns om te kan bid nie, maar Hy pleit "vir die heiliges" (huper hagion).

Ons moet verder gaan en stel dat Paulus die hele nuwe lewe van die kinders van God as ' $n$ wonder sien. God doen in sy kinders wat die mens nie kan doen nie, selfs nie al ken hy die wet en probeer dit gehoorsaam nie. Die wet self is "nie by magte" om die mens te heilig nie (Rom. 8:3), maar as die Gees die lewe beheers, dan gebeur die wonder dat die oue verbygaan en die "nuwe skepping" as 'n nuwe mens verskyn $(2$ Kor. $5: 17)$. Hierdie vernuwing is ' $n$ wonder, want dit is ' $n$ gawe van God wat nie bloot deur die kragte van die bestaande mens werk nie. Die doring in die vlees, die swakheid van die liggaam, bevorder eerder die vloei van God se krag (2 Kor. 12:7-10) want "die sterwe van Jesus dra ons altyd saam in ons liggaam, sodat ook die lewe van Jesus sigbaar kan word in ons liggaam" (2 Kor. 4:10). Dit gaan om die wonderkrag van Jesus se opstanding wat ons na sy beeld herskep (Fil. 3:10).

In al hierdie dinge het ons nie met uitsonderlike ervaarbare aspekte van die Gees te doen nie, maar met 'n wesenlike kwaliteit van Paulus se pneumatologie. Die Gees is vir hom wesenlik die wyse waarop Christus ervaarbaar by ons teenwoordig is. Die ervaarbaarheid is maar een kant van sy Geesbegrip, maar dit is wesenlik. Gal. 3:1-6 is ' $n$ aanduiding hiervan. Paulus bekommer hom daaroor dat die Galasiërs die weg van die Gees verlaat het en na die weg van die wet afgewyk het. Hy wil hulle oorreed om na die weg van die Gees en van vrye genade terug te keer. In hierdie gedeelte span hy die argument in dat hulle tog nog kan onthou dat hulle die Gees eers ontvang het toe hulle die evangelie begin glo het (vers 2). Hy gaan daarvan uit dat niemand daaroor kan stry of die Galasiërs die Gees ontvang het nie, want dit was 'n konkrete, ervaarbare gebeurtenis. Vers 5 verwys na 'n aspek van hierdie ervaring deur te sê dat God saam met die gawe van die Gees kragte (dunameis) onder hulle gewerk het. ${ }^{45)}$ Die res van die brief benadruk dat die Galasiërs die vlees 
slegs deur die krag van die Gees sal kan oorwin, en ons moet verstaan dat Paulus hierdie krag in ' $n$ direkte, ervaarbare sin bedoel. Die inwoning van die Gees is dus nie net 'n saak wat geglo word nie, maar wat ter bevestiging van dié geloof ook ervaar word.

Teen hierdie agtergrond kan ons nou die moeilike vraag benader hoe ons die leiding van die Gees in Rom. 8:14 en Gal. 5:18 moet verstaan. Die werkwoord agein word vir die leiding van die Gees gebruik, en die demoniese keersy vind ons in 1 Kor. 12:2 waar Paulus sê dat die heidene na die afgode "meegevoerd meegesleur word" (êgesthe apagomenoi), d.w.s. blindelings meegevoer word. Moontlik is die verwysing na ekstatiese meevoering deur die demone, maar ook al sou dit nie die geval wees nie, is die bedoeling in elk geval dat die heidene nie beheer oor hulleself het nie deurdat hulle in die mag van die afgode geval het. ${ }^{46)}$ Käsemann ${ }^{47}$ aanvaar dat dit oor ekstase handel, en sê ons moet ook Rom. 8:14 in dié lig verstaan: dit is entoesiastiese spraak, en die bedoeling is dat die gelowiges deur die Gees as ' $n$ vreemde mag gedryf word.

Met hierdie uitleg gaan Käsemann te ver. Rom. 8:14 is met ' $n$ want aan die vorige vers verbind, sodat ons daaruit meer inligting kan kry oor hoe die leiding van die Gees funksioneer. Daar staan dat die kinders van God deur die Gees die praktyke van die sondige natuur doodmaak. In die vorige vers word dit as ons "verpligting" gestel om dit te doen. Die tipiese Pauliniese wisselwerking tussen indikatief en imperatief word dus behou waar dit oor die leiding van die Gees gaan. Die Gees sleep ons nie willoos mee nie; sy leiding skakel ons wil en inspanning nie uit nie, maar in. ${ }^{48)}$ Die afgodiese geeste voer mense magteloos mee, maar die Heilige Gees skep ruimte vir die subjek. Die indikatief van sy werk loop telkens ook op ' $n$ imperatief uit wat 'n beroep op die wil van die subjek doen.

Die verband waarin die leiding van die Gees in Gal. 5 voorkom, bevestig dit. Gal. 5:16-18 is 'n eenheid met die struktuur van 'n ringskomposisie, omdat die gedagte van vers 16 in vers 18 herhaal word. Aan die einde van die perikoop word dié gedagte weer in vers 25 herhaal. Daarom staan "gelei word deur die Gees" (18) parallel aan "deur die Gees wandel" $(16,25)$. Dit word as 'n opdrag gegee dat ons deur die Gees moet wandel. Vers 17 verduidelik dat die Gees ons nie magteloos meevoer nie, maar juis van die magteloosheid verlos. Die gelowige wat nog nie volledig onder die beheer van die Gees lewe nie, kan nie doen wat hy wil nie. Die bedoeling is dat die innerlike stryd tussen die vlees en die Gees hom lamlê, sodat hy nie so ver kom om die kwaad of die goed wat hy wil doen, uit te voer nie. ${ }^{49)}$ Wanneer die Gees egter die beheer oorneem, word ons vrygemaak van die wet en die vlees, sodat ons God se opdrag om mekaar in liefde te dien, kan uitvoer (13). Die wil van die 
gelowige subjek word nie in die leiding van die Gees opgelos nie, maar dit word genees en bekragtig, sodat dit God se wil in vrye gehoorsaamheid kan volg. Die verhouding tussen die gelowige en die Vader is 'n persoonsverhouding, en die gevaar van die mistiek en die spiritualisme is dikwels dat daar ' $n$ vorm van eenwording nagejaag word wat die persoonsverhouding oplos. ${ }^{50}$ )

Nou moet ons egter ook in die ander rigting kyk en die teenoorgestelde gevaar raaksien. Ons moet nie net beswaar maak as die aktiwiteit van die gelowige in die leiding van die Gees opgelos word nie, maar omgekeerd ook as die leiding van die Gees min of meer in die aktiwiteit van die gelowige opgelos word. Diegene wat die werksaamheid van die Gees anders as Paulus nie meer as ervaring beleef nie, kan maklik daartoe oorgaan om die leiding van die Gees tot 'n geloofsbeginsel te reduseer wat in werklikheid op weinig meer neerkom as dat die gelowige op grond van die heil in Christus probeer om te onderskei wat God se wil in elke situasie is. Die leiding van die Gees beteken dan dat die mens begeer en glo dat die Gees sy lewe vorm en dat hy hom in sy gedrag deur die Skrif laat lei, maar nie dat die Gees self hom werklik lei nie. Die leiding van die Gees smelt dan saam met die onderskeiding van die wil van God wat die gelowige op grond van die Skrif probeer uitoefen. Rom. 12:2, wat sê dat die gelowige met sy vernieude denke in staat is om te onderskei (dokimazein) wat die wil van God is, word dan as die enigste maatstaf vir die leiding van die Gees geneem. ${ }^{511}$

Alles wat ons reeds gesien het oor die element van die wonder en die direkte handele in Paulus se Geesbegrip, laat ons vermoed dat ons in die bg opvatting oor die leiding met ' $n$ westerse, rasionalistiese reduksie te make het. Die onmiddellike verband in Rom. 8 toon reeds dat die element van direktheid steeds in Paulus se Geesbegrip teenwoordig is. Ons het reeds gesien dat die Abba-roep van vers 15 en die intrede vir ons onvermoë om te bid in vers $26-27$ nie verklaar kan word sonder verwysing van die misterie van ' $n$ werksaamheid van die Gees wat van buite af direk na ons toe kom nie. Eksegete gebruik dikwels vers 16 om te argumenteer vir die gedagte van 'n samesmelting tussen die Geestelike en menslike aktiwiteit. Daar staan dat die Gees saamgetuig (summarturei) met ons gees dat ons kinders van God is. H. Ridderbos lê klem op die saam en sê dat dit dus nie oor 'n "afzonderlijke spreken" gaan nie, maar oor "het invloeien van het getuigenis van de Geest in dat der gelovingen". ${ }^{521}$ Feit is nou egter dat dit waarskynliker is dat summarturei in die betekenis van ' $n$ verbum simplex gebruik is, sodat die vers beteken dat die Gees aan ons gees getuig. ${ }^{53}$ Een argument hiervoor is dat dié getuienis van die Gees dan by die Abba-roepe van die vorige vers aansluit in die sin dat dit o.a. daardeur gelewer word. As dit reg is, is vers 
16 dus nie 'n bewys vir die ineenvloei van Geestelike en menslike aktiwiteite nie, maar 'n aanduiding van die element van extra nos in die Gees se werk.

Om ' $n$ vollediger voorstelling te kry van Paulus se gedagtes oor die leer ken van God se wil, moet ons Kol. 1:9 saam met Rom. 12:1-2 lees. Daar staan dat Paulus bid dat die gelowiges in Kolosse "vervul mag word met die kennis van God se wil deur al die wysheid en insig wat die Gees gee". Die volgende vers maak dit duidelik dat dit hier nie bloot om God se algemene wil of wet gaan nie, maar om sy praktiese wil wat ons met die oog op die daaglikse wandel moet ken. Smelt die aktiwiteit van die Gees hier saam met die eie denke waardeur hierdie wil onderskei moet word? Die vers laat klaarblyklik die opening vir meer. Die gebed lui dat die gelowiges vervul moet word (passief) met die kennis van God se wil, en die bedoeling is dat God hulle sal vervul. ${ }^{54}$ ) God help ons nie net om sy wil te onderskei nie, maar Hy gee die kennis daarvan in ons harte. Hierdie kennis van God se praktiese wil is gebaseer op 'n kennis van sy heilswil soos geopenbaar in Christus. Dieselfde twee woorde wat in Kol. 1:9 in verband met eersgenoemde gebruik word, word in Kol. 2:2 aan laasgenoemde verbind, naamlik insig (sunesis) en kennis (epignosis). Die heilswil word hier die misterie genoem, en ons het reeds gesien dat dit volgens Paulus se beskouing deur die Gees geopenbaar is (byvoorbeeld 1 Kor. 2:10).

Ons moet die hele saak in verband met die profesie in die vroeë gemeentes sien. Ons het reeds gesien dat die profete openbaringe ontvang en bekendgemaak het. Hierdie openbaringe het nie net God se algemene heilswil bekendgemaak nie, maar ook sy praktiese wil. In Hand. 13:2 het die Gees kennelik d.m.v. profete aangedui dat die eerste sendingreis aangepak moet word, ${ }^{55)}$ en ons het reeds gesien dat daar nog baie sulke voorbeelde in Handelinge is. Volgens $1 \mathrm{Tim}$. 1:18 en 4:14 het God ook deur profete bekendgemaak wat Timoteus se roeping is. ${ }^{56)}$ Direkte openbaringe het dus 'n rol gespeel in die wyse waarop die vroeë Christene God se wil moes leer ken. Hulle was nie almal profete nie, maar Paulus leer dat almal daarna moet streef om die gawe van profesie te ontvang, m.a.w. elkeen moes daarna verlang dat daar so ' $n$ mate van openheid tussen hom en die Gees ontwikkel dat die Gees sy wil ook direk kan bekendmaak.

Dit is duidelik dat ons ons hierdie bekendmaking nie so moet voorstel dat alle nadenke en onderskeiding daarmee uitgesluit word nie. Selfs die pertinente profesieë wat aan die gemeente oorgedra is, moes nie onkrities aanvaar word nie. Hulle moes deur ander beoordeel word (1 Kor. 14:29) en getoets word sodat net die goeie behou kon word (1 Tess. $5: 21)$. Die vermoë om die geeste te onderskei, naamlik om vas te stel of 
'n profesie of iets dergeliks werklik deur die Heilige Gees gegee is, is selfs een van die charismata $\left.(1 \mathrm{Kor} .12: 10) .{ }^{57}\right)$ Paulus beveel dat alle profesie "in ooreenstemming met die maat van die geloof" beoefen moet word (Rom. 12:6), en dit beteken waarskynlik dat die inhoud van die profesie met die geloofsinhoud van die gemeente moet strook.

Hieruit kan ons aflei dat elkeen wat meen dat die Gees hom op 'n sekere pad lei, daardie gedagte as voorlopig moet beskou, en bereid moet wees om dit self of met behulp van ander gelowiges te toets. Die Gees lei nie so dat ons sonder meer kan bewys dit is Hy wat gelei het nie; Hy lei nie so dat ons blindelings kan volg nie. Die belangrikste is dat ons steeds ons onderskeidingsvermoë moet inspan om seker te maak of die vermeende leiding met die Skrif strook.

Kan daar meer duidelikheid uit Paulus verkry word oor die wyse waarop die Gees lei? Die menslike kant van die leiding verstaan ons die maklikste. Die Gees vernuwe die hele mens, die denke (nous) ingeslote (Rom. 12:2), sodat Hy die mens met wysheid, insig en fyn aanvoeling vul (Kol. 1:9; Fil. 1:9) om die Woord toe te pas en sodoende te onderskei wat God se wil is. Die vraag wat Paulus se pneumatologie aan ons opdring is egter of die leiding van die Gees nie ook 'n meer direkte kant bevat nie. Gee Hy naas insig ook spesifieke insigte of ingewings? Laat Hy naas wysheid ook oortuigings by ons tot stand kom oor wat God wil hê? In die lig van die briewe van Paulus is dit klaarblyklik onmoontlik om hierdie vrae ontkennend te beantwoord. Maar verder as dit kan ons nouliks kom. Hoe die direkte aspek van die leiding van die Gees dan presies werk, spel Paulus nie uit nie. Hy beskryf byvoorbeeld nie luistertegnieke soos die Morele Herbewapening nie. Ons kan verstaan waarom hy nie so ver gaan nie. Hier het ons met die misterie van die Gees se eie werk te make. Hy self weet hoe Hy dit doen, en ons kan ons bloot vir sy leiding oopstel in die vertroue dat $\mathrm{Hy}$ sal lei. Dit is goed dat ons nie weet hoe sy direkte leiding na ons kom nie, want anders sou ons die Gees deur tegnieke probeer vang het en hoogmoedig geraak het op ons vermeende sekere kennis van God se wil. Nou is ons verplig om, ook al meen ons dat ons direkte leiding ontvang, baie beskeie te bly.

As selfs beweerde profetiese openbarings beoordeel moes word, is dit duidelik dat die direkte leiding van die Gees nie van die eie onderskeiding en nadenke van die gelowige geskei kan word nie. Dit moet erken word sonder om eersgenoemde in laasgenoemde op te los. Die gelowige moet hom nie net op sy eie onderskeidingsvermoë rig nie, maar ook wagtend en luisterend op die Gees self. ${ }^{58)}$ 


\section{KONKLUSIES}

\subsection{Die Gees en die Woord}

Dit is duidelik dat Luther se standpunt dat die Gees slegs deur die uiterlike van die Woord sy innerlike werk kan doen, nie houdbaar is nie. In die lig van die omstandighede van die Reformasietyd is dit verstaanbaar dat daar veral by Luther 'n oorreaksie was. Toe die gesag van die RoomsKatolieke Kerk verval het, het die gevaar ontstaan dat subjektivisme die kerk in ordeloosheid sou dompel, soos ook uit die optrede van die Anabaptiste e.a. geesdrywers geblyk het. Om hierdie gevaar die hoof te bied, het Luther die ganse geestelike lewe in 'n oorreaksie uitsluitlik aan die uiterlike Woord verbind. ${ }^{59}$ )

Calvyn het nie so ver gegaan nie. Hy het die basiese konsep behou, maar ruimte gelaat vir uitsonderings. Teenoor die gevaar van die Spiritualisme bly hy daarby dat die Skrif die enigste werklike instrument van die Gees is, maar hy voel verplig om uitsonderings te maak vir 'n meer onmiddellike werksaamheid van die Gees t.o.v. sake soos die kinderdoop en gebed. Die vraag is of daar nie ' $n$ meer bevredigende oplossing vir die probleem gevind kan word, sodat uitsonderings nie nodig is nie.

Dit lyk of die oplossing daarin geleë kan wees dat ons die Gees nie aan die Woord as Skrif verbind nie, maar aan die Lewende Woord, d.w.s. Christus. Die Gees se werk is nooit iets anders nie as dat $\mathrm{Hy}$ Christus aan ons meedeel. Hy bring geen nuwe openbaringe nie, maar lei ons steeds dieper in die openbaring van Christus in. Sy leiding kom altyd daarop neer dat Hy ons help om die betekenis van hierdie openbaring beter in ons lewens te realiseer. In hierdie lig is daar dan geen beswaar om te sê dat hierdie leiding sowel deur middel van die Woord as onmiddellik na ons kan kom nie. Die Gees kan selfs openbaringe aan ons gee om ons te wys wat die Openbaring nou vir ons beteken. Dit is 'n gevaarlike opening wat die Skrif hier laat, want mense wat beweer dat hulle onmiddellike leiding ontvang het, kan hulle vergis. Daarom help die Gees die gemeente om te onderskei, en gee Hy selfs die gawe van onderskeiding. Die maatstaf van die onderskeiding is die "maat van die geloof" (Rom. 12:6), wat op die inhoud van die Skrif neerkom. Die Skrif is die maatstaf, maar nie die uitsluitlike middel nie.

Waar Luther en in 'n mindere mate Calvyn dus probeer het om 'n formele beskerming teen die spiritualisme aan te lê, $\mathrm{nl}$. die beperking van die werk van die Gees tot die Woord, stel ons hier voor dat ons met 'n inhoudelike beskerming tevrede moet wees, $\mathrm{nl}$. die onderskeiding van die inhoud van die leiding aan die hand van die Skrif. Dit lyk moeiliker om die 
stryd tot inhoudelike terrein uit te brei, maar ons kom in elk geval nie daarvan weg nie, omdat die Skrif self ook op 'n duisend maniere waninterpreteer kan word. ${ }^{601}$

Hierdie openheid vir die onmiddellike leiding van die Gees hoef glad nie ons ywer om sy leiding in die Skrifte soek, te demp nie. Eers as die boek van die Gees ons deurdrenk, ken ons Hom, en kan ons sy onmiddellike stem herken. Sy leiding deur die Skrif en sy onmiddellike leiding kan nie geskei word nie. Gewoonlik sal ons juis wanneer ons met die Skrif besig is, op ons ontvanklikste wees vir sy direkte leiding. ${ }^{611}$ En 'n gevoelige verstaan van die Skrif, wat alleen onder leiding van die Gees moontlik word, bly steeds ons absolute maatstaf.

\subsection{Die Gees en ons denke}

Die vraagstuk van die direkte werksaamheid van die Gees het twee aspekte: die verhouding tussen die Gees en die Woord, en die verhouding tussen die Gees en menslike denke. Soos ons reeds gesien het, is dit moontlik om te glo dat die Gees wel onmiddellik werk, maar om hierdie werksaamheid dan in so ' $n$ mate in die denke van die mens te laat opgaan, dat die eie aard van die Gees se werksaamheid daarin opgelos word en verlore gaan. Dan word die Gees tot 'n ander middel beperk, $\mathrm{nl}$. die menslike onderskeiding. Die mens glo dan dat die Gees in sy denke werksaam is, maar ervaar dit nie. ' $n$ Toegepaste sunergisme of samewerkingsbeginsel bepaal alles, en die gelowige ervaar geen van sy insigte meer as gawes van God nie. Die extra nos gaan dan op die terrein van die pneumatologie verlore; die Gees word gedomestiseer tot daar weinig van sy vreemdheid oorbly.

Ons moet sien dat dit gerieflik met ons gangbare wêreldbeskouing strook om die leiding van die Gees so te sien. Aristoteles het gesê dat 'n mens slegs deur waarneming of argumentasie kennis kan opdoen, en oor die algemeen bly ons nog steeds in die ban van so ' $n$ geslote wêreldbeskouing. Daarvolgens is dit nie moontlik dat die Gees van buite at vir 'n mens iets in die gedagtes gee nie. ${ }^{62)}$ Daarvolgens moet alle gebeurtenisse natuurlike oorsake hê, en is daar in beginsel nie plek vir die wonder nie. Wanneer mense met so 'n algemene wêreldbeskouing tot geloof kom, moet hulle natuurlik plek inruim vir wonders, maar daardie plek is dan gewoonlik beperk. Van ons gereformeerde vaders het wonders tot die tyd voor die afsluiting van die Kanon beperk, en baie van ons beskou wonders in elk geval as uitsonderlik. Ons moet erken dat ons ons deur 'n Bybelvreemde wêreldbeskouing laat deurdrenk het wat wesenlik daarteen is om die geestelike deel van die werklikheid as werklik te beskou. Ons sal weer by Paulus en die ander openbaringsgetuies 
skool moet gaan om te leer dat die hele lewe van die Christen eintlik ' $n$ wonder is. Dan sal ingewings en helder denke oor God se wil nie meer vir ons teenoor mekaar staan nie, omdat die blote feit dat die Gees ons ganse innerlike vernuwe alreeds ' $n$ bomenslike wonderwerk is. Dan sal ons te alle tye op 'n ontspanne, nugter wyse oop staan vir die misterie van die Gees se onmiddellike werksaamheid.

As ons dit afwys dat die Gees se leiding in die menslike denke opgelos word, sluit dit nie uit dat die Gees se leiding in ons denke invloei sodat ons verantwoordelike beslissings neem voor ons handel nie. Dat direkte leiding nie refleksie uitskakel nie, het ons reeds gesien toe ons gekyk het hoe Paulus die optrede van die profete aan die beoordeling van die gemeente onderwerp. As selfs ' $n$ vermeende openbaring wat ' $n$ profeet ontvang het nie sonder beoordeling aanvaar moet word nie, hoeveel te meer sal dit nie van die meer algemene "influistering" van die Gees geld dat dit beoordeel moet word nie. Dit is tipies van die Spiritualisme dat dit wil skei tussen die werksaamheid van die Gees en van die mens, en dus die ingewings van die Gees ongereflekteerd sal wil volg, maar saam met Paulus verwerp ons hierdie skeiding in watter vorm dit ook al voorkom. ${ }^{63}$. As gereformeerdes is ons daarvoor bekend dat ons goed bewus is van die corruptio totalis, en ons moet daarby bly. Ons moet besef dat die gevaar steeds bestaan dat ons sondige hart ons kan wysmaak dat hy ingewings ontvang het as hy eintlik net sy eie wil wil sanksioneer. Ons moet besef dat die werk van die Gees gewoonlik sodanig is dat mense nie kan bewys dat dit $\mathrm{Hy}$ is wat gewerk het nie. Die groot gevaar van die deur wat ons oopstoot na direkte leiding, is selfverheffing. As ons onsself onder die tug van die Woord hou, sal ons baie beskeie wees wanneer ons meen dat ons direkte leiding ontvang, en bereid wees om in die lig van die Skrif krities daaroor na te dink en dit selfs met ander gelowiges te bespreek. Hierdie dinge is so gevaarlik dat ons eintlik net binne die ruimtes van die ware kerk daaroor mag fluister.

Wanneer ons die leiding van die Gees op hierdie wyse in ons denke opneem, ontneem dit hierdie leiding nie sy misterie en vreemdheid sodat dit in ons denke opgaan nie. Natuurlik is die leiding van die Gees ook deel van ons denkprosesse self in die sin dat $\mathrm{Hy}$ ons hele wese vernuwe, maar dit is nie al nie: die leiding kan ook van buite op ons afkom, extra nos, sodat ons dit as 'n gawe, ingewing ontvang. Die praktiese navolging van die leiding wat ons ontvang moet nie net die element van getrou bly aan ons insigte bevat nie, maar ook die element van gehoorsaamheid aan 'n gesag wat buite en bo"ons staan. ${ }^{64}$ ) 


\subsection{Na die praktyk}

Op hierdie terrein moet ons aan twee kante van die werklikheid vashou: verantwoordelike denke en openheid vir die misterie van die Gees se werksaamheid. Dit is duidelik dat ons in 'n tradisie en wêreldbeskouing staan waarin ons meer van die denke as van die misterie maak. Ons praat nog baie oor die Gees, maar die vraag is of ons Hom nie dermate gedomestiseer het dat sy gans andersheid, sy vreemdheid, die kragtige bevryding van sy eie werksaamheid verdring word nie. In ons teologie loop ons gevaar dat verantwoordelike denke en wetenskaplikheid die openheid vir die misterie van die Gees wat ons alles wil leer i.v.m. die openbaring oorwoeker. Ons sal daarby moet stilstaan dat die Parakleetuitsprake in Joh. 14-16 aandui dat die Gees ons aktief wil lei in die verstaan van die openbaring, dat Hy ons begrip wil gee wat ons self nie kan vind nie, en dat 1 Kor. 2 beteken dat net $\mathrm{Hy}$ die geheimenis van Christus aan ons kan openbaar en ons die regte woorde kan leer om dit oor te dra. Dan sal ons besef dat alle teologie gedra moet word deur 'n wag op die leiding van die Gees, en dat sy leiding nie net beteken dat Hy ons help dink nie, maar ook dat Hy ons wys en laat sien.

In wese is alle kerklike vergaderings ' $n$ soeke na die praktiese leiding van die Gees. Dit is ' $n$ vraag of ons vergaderings nie veels te na aan die rasionalisme beweeg het nie. Moet daar nie meer op leiding gewag word en selfs op die werksaamheid van die gawe van profesie onder ons nie?

As ons oor ons persoonlike Bybelstudie moet praat, wys die naam wat ons daaraan gee reeds die invloed van die rasionalisme. Is ons nie met so 'n ywerige studie van die Bybel besig dat ons nie meer ruimte laat vir luisterende meditasie oor die Skrif nie? Is ons in ons gebede nie ook so vol woorde en gedagtes dat ons die moontlikheid dat die Gees ons gebede volgens Rom. 8 lei, verdring nie? T.o.v. die stiltetyd lyk dit of dit ietwat te ver gaan om soos die Morele Herbewapening 'n aparte tyd vir luister opsy te sit. Dit ruik na spiritualisme om te dink dat die Gees nou in 'n spesifieke tyd sal praat. Dit lyk beter om te praat van 'n stiltetyd waarin daar onder andere luisterende meditasie oor die Skrif plaasvind, en waarin die gebed ook die kwaliteit van openheid vir die leiding van die Gees bevat. Ons sal ons lidmate hierin opvoed as ons meer ruimte vir stilte en meditasie in ons eredienste maak, bv. 'n tyd vir nadenke na die Skriflesing soos in die Church of the Province.

As ons meer openheid vir die leiding van die Gees in ons stiltetyd beoefen, sal ons vind dat die Gees ook deur die loop van die dag van hierdie openheid gebruik maak, sodat sy leiding vir ons 'n groter werklikheid word. Voor hierdie misterie is dit die beste om nie te probeer 
uitspel hoe dit plaasvind nie, maar net met sekerheid dat dit 'n werklikheid is, daarop te wag. ${ }^{65)}$ Dit is so moeilik om ons lewensomstandighede te beoordeel, dat ons werklik die lig van die hemel nodig het om te kan sien wat ons roeping in elke situasie is. Hoe wyer ons na ons situasie kyk, hoe ingewikkelder raak dinge. As ons die maatskaplike strukture waarin ons geplaas is, moet beoordeel, het ons met ' $n$ saak van so 'n buitengewone kompleksiteit te make dat ons werklik daarvan afhanklik is dat die Gees ons as't ware 'n gesig moet laat sien van wat werklik aan die gang is, en ' $n$ visie moet gee van wat gedoen kan word.

Per slot van sake moet ons onthou dat ons nie oor 'n krag praat nie. maar oor ' $n$ Persoon waardeur die lewende Christus self by ons teenwoordig is. Hy het ons lief, en verlang na voortdurende persoonlike kontak met ons. Die leiding van die Gees berus daarop dat ons in die mees intieme moontlike voeling met 'n Persoon kan lewe. ${ }^{66)}$

\section{Notas}

1. L. Richter en A. Adam, $R G G^{3}$ IV, 1237 e.v.; W.D. Jonker, Die Gees van Christus, Pretoria 1981, 42-55. Ons gaan hier nie in op afgewaterde vorme van mistiek wat onder die tug van die Woord gebring is, bv. by Augustinus, en in die kerk min of meer aanvaarbaar geword het nie.

2. P.N. Kruyswijk, "De Heilige Geest in de middeleeuwse mystiek", in: De Heılige Geest (red. J.H. Bavinck) Kampen 1949, 195-196.

3. K. Nürnberger, Sistematiese Teologie, Genadendal 1975, 383.

4. Vgl J.F.G. Goeters, $R G G^{3}$ VI, 255-257.

5. Vgl. A.B.W.M. Kok, "De Heilige Geest en de latere geestdrijverijen", in: De Heilige Geest, 286-287; P. Held, RGG V, 730. Die boeke van Richard Foster het tans oral groot invloed t.o.v. meditasie en die ander "spiritual disciplines". Hulle kan vir ons geestelik van waarde wees, mits ons daarop bedag is dat Foster ' $n$ Kwaker is en dus tot 'n tradisie behoort wat nie dieselfde versigtigheid teenoor spiritualisme aan die dag lê as die gereformeerde tradisie nie.

6. Vgl. Schaff-Herzog, Encyclopaedia of religious knowledge VI, London $\pm 1920,321$; H.I. Lederle, Treasures old and new, diss. Unisa 1985, 372 maak ook beswaar teen hulle inherente triomfalisme waardeur hulle naby aan perfeksionisme kom.

7. H. Rendtorff, $R G G$ 1, 1467.

8. P. Howard, Frank Buchman's secret, London 1961, 23.

9. J. du Plessis, Het leven van Andrew Murray, Kaapstad 1920, 466-467, 490.

10. Vgl. bv. sy Op God wag, vertaal deur F.J.B. Malan, Stellenbosch 1941, 13-16 en The Spirit of Christ, London, latere uitgawe 1963, 129-130.

11. A.D.R. Polman, "De Heilige Geest en de strijd der Reformatoren", in: De Heilige Geest, 220; H. Bavinck, Gereformeerde Dogmatiek IV, Kampen 1911, 500-501.

12. H. Berkhof, The doctrine of the Holy Spirit, Richmond 1964, 38; Bavinck, a.w. IV, 503.

13. Jonker, a.w., 56 .

14. Institutio $1,9,1$.

15. Inst. 1, 9, 3 (vertaling van F.L. Battles, Philadelphia 1960).

16. Inst. 3, 1, 3-4.

17. Inst. $3,2,34 ; 3,1,4$. 
18. Inst. 1, 7, 5 .

19. Vgl. Berkhof, a.w., 37-38; Bavinck, a.w. 1, 626 bly by Calvyn se standpunt; G.C. Berkouwer, De Heilige Schrift 1, Kampen 1966, 45-74 skep die indruk dat hy ietwat van die element van die addisionele wegstuur deur te benadruk dat dit oor die oortuigingskrag van die Skrifboodskap gaan. M.i. korrek is S. van der Linde, De leer van den Heiligen Geest bij Calvijn, Wageningen 1943, 77-80.

20. Inst. 4, 16; Jonker, a.w. , 57, 92.

21. Inst. 4, 3, 11.

22. Inst. 2, 20, 5 .

23. Inst. 3, 1, 3; Corpus Reformatorum 11, Brunsvigae 1864.

24. Jonker, a.w., 84 .

25. Jonker, a.w., 92-93, 97.

26. Een van die duidelikste bewyse hiervan is die byvoeging van hierdie saak in die Joëlsitaat in Hand. 2:18; vgl. ook E. Schweizer, ThWVI, 406-407 en E. Käsemann, RGG 11, 1276-1277.

27. Paulus is nie ' $n$ akademiese teoloog met ' $n$ pneumatologie in die eintlike sin van die woord nie, maar t.w.v. bondigheid gebruik ek die term in oneintlike sin.

28. Paulus. Ontwerp van zijn teologie, Kampen 1966.

29. G. Friedrich, ThW VI, 856.

30. Vgl. veral sy Theologie des Neuen Testaments, Tübingen ${ }^{6} 1968$ (oorspronklik 1958), $332-341$.

31. A.W. 43 .

32. A.W. , 155- 166 .

33. A.w., 337-338.

34. ThW VI, 1959, 425.

35. Kyrios und Pneuma, SANT, München 1961, 143. Hy beklemtoon die ervaarbaarheid van die Gees sterk, maar by nader insien word dit duidelik dat hy die lewensvernuwende werking van die Gees in 'n wye sin bedoel.

36. Traditionsgeschichtliche Untersuchungen zur Paulinischen Pneumatologie (diss. Utrecht), Assen 1973, 144-146.

37. $R G G^{3} 11,1274-1275$.

38. "Der gottesdienstliche Schrei nach der Freiheit", in: Paulinische Perspektiven, Tübingen 1969, 216.

39. An de Römer (HNT), Tübingen 1973, 216.

40. Vgl. Käsemann, a.w., 1969, 212-214.

41. Die duidelikste voorbeeld wat ek kon vind van 'n eksegeet wat hierdie integrasie raakgesien het, is 0 . Kuss. In sy Der Römerbrief 11, Regensburg 1959, 540-595 bied hy 'n uitvoerige en verhelderende ekskurs oor die Gees by Paulus. ' $n$ Ander eksegeet wat hiermee in harmonie is, is L. Cerfaux wat in sy Le Chrétien dans la théologie pauliennes, Paris 1962 (ek gebruik die Nederlandse vertaling van Patmos, Antwerpen 1964) uitvoerig aan Paulus se pneumatologie aandag wy, en inset met die charismata waarvoor Paulus volgens hom besonder gevoelig is (228). Die openbaring van die geheimenisse van Christus en die orige werksaamheid van die Gees lê vir hom op een lyn met die gawe van die charismata (295).

42. H. Schlier, Der Brief an die Galater (KEK), 4. Auflage der Neubearbeitung, Göttingen 1965, 199.

43. H. Schlier, Der Römerbrief (HThKNT), Freiburg 1977, 254 e.v.; U. Wilckens, Der Brief an die Römer (EKK), Zürich 1980, 161-162; H. Ridderbos, Aan de Romeinen, Kampen 1959, 191; E. Käsemann, An die Römer (HNT), Tübingen 1973.

44. Käsemann, a.w.; O. Kuss, Der Römerbrief 11, 549-550.

45. E. Schweizer, ThW VI, 426; H. Schlier, Galater, 125-126; D.J. Lull, The Spirit in 
Galatia, SBL dissertation series no 49, 1980, 72-74.

46. H. Conzelmann, Der erste Brief an die Korinther (KEK), Göttingen 1969, 242-243.

47. Käsemann, a.w., 216.

48. So ook Wilckens, a.w., 136 en Schlier, Römerbrief, 251.

49. Vgl. Schlier, Galater, 248-250.

50. Vgl. W.D. Jonker, Die Gees van Christus, Pretoria 1981, 55.

51. W.C. Coetzer, Die wandel na die Gees in die brief aan die Galasiërs (diss. Unisa 1983) reduseer die leiding van die Gees min of meer tot ' $n$ beginsel en motiveringskrag. Hy noem dit 'n "nuwe prinsiep en norm" sowel as 'n "bron en motivering" vir ons daaglikse lewe, waarin dit gaan om "daaglikse toepassing en realisering" van die heil (168-170). Ek vind egter nie besinning oor die misterie van die direkte leiding van die Gees in die boek nie. D.J. Lull, a.w., beklemtoon dat die Gees 'n mag is wat die mag van die vlees in ons vervang, maar besin eweneens nie oor die moontlikheid van direkte leiding nie.

52. Romeinen, 182

53. So bv. die Romeine-kommentare van Schlier, 254; Wilckens, 138; Käsemann, 218 en O. Kuss, a.w. 605, wat ook Lietzmann, A. Maier, Zahn, H. Bertram en H. Strathmann (ThW IV, 515) aanhaal.

54. Vgl. E. Lohse, Die Briefe an die Kolosser und an Philemon (KEK), Göttingen 1968, 56.

55. Schwelzer, ThW VI, 405-407.

56. Ridderbos, Paulus, 504.

57. Ridderbos, Paulus, 504.

58. In sy uitleg van Gal. 5:16 formuleer H. Schlier $(1965,248)$ goed: Paulus bedoel "dass ihr im Achten und Hören auf den Geist, im Gehorsam gegen den Geist und in der Aktivität des Geistes, der euch führen will, euer Leben vollziehen sollt".

Andrew Murray, The Spirit of Christ, 129-130, lê Rom. 8:14 so uit dat hy 'n openheid laat vir die direkte leiding van die Gees sonder om die myse daarvan te probeer uitspel. Hy waak teen spiritualistiese neigings deur te sê die leiding kom gewoonlik nie d.m.v. sterk indrukke of innerlike stemme nie. Dit wil dus voorkom of hy Paulus op hierdie punt goed verstaan. A.S. Wood, Paul's Pentecost (An Exposition of Rom 8), Paternoster Press 1963, 61, 72 gaan miskien effens te ver deur te sê dat gelowiges elke minuut van hulle lewe onder die "guidance" van die Gees kan lewe wat d.m.v. "compulsion" en "suggestion" in 'n mens se gedagtes opkom.

59. Nader aan ons is dit tiperend dat die Lutheraan K. Nürnberger, Sistematiese Teologie, 380-381 steeds daarby bly dat die Gees subjektiewe belewenisse slegs deur die Woord bewerk.

60. Calvyn se uitleg van 1 Tess. 5:19-20 is 'n goeie voorbeeld van hoe ons op grond van korrekte eksegese van hom moet verskil. Paulus vermaan ons om die profete wat in die gemeente mag optree nie gerıng te skat nie, en Calvyn verstaan dit as 'n verwysing na die profetiese boeke van die Ou Testament, en gebruik dit as 'n bewys dat die Gees saam met die Woord werk (/nst. 1.9.3).

61. Morton Kelsey, Encounter with God, Minneapolis 1972, 36 noem die pentekostaliste as bewys vir hierdie harmonie: hulle benadruk die direkte werk van die Gees, maar is tegelykertyd ywerige Bybellesers.

62. 'n Voorbeeld hiervan is dat A.A. Kuyper se Inwige twee volumes oor die Gees, Het werk van den Helligen Geest, Kampen 1927, volgens die indeks niks oor die leiding van die Gees bevat nie; ook dat A.B.W.M. Kok, "De Heilige Geest en de latere geestdrijverijen", in: De Heilige Geest, 294-298 sê dat profesie tot die beginfase van die kerk beperk is en dat daar nie meer aparte direkte aanwysings van die Gees hoef te kom nie, omdat sy leiding ons denke deurdring. 
63. Vgl. W.D. Jonker, Die Bybe/ en Gods wil vir ons lewe, Kaapstad 1974, 4-5. Hy beklemtoon so sterk dat die Gees deur ons begripsvermoë werk, dat die vraag ontstaan of hy nie weer te ver in ' $n$ anti-spiritualistiese rigting beweeg nie.

64. Thomas Aquinas het van innovationes gepraat. K.C. Kinghorn, Fresh wind of the Spirit, Nashville 1975, 79-87 skryf op 'n aanvaarbare myse oor die luister na die Gees. D. Ewert, The Holy Spirit in the New Testament, Kitchener 1983, 224 e.v. skryf op ' $n$ ietwat eensydige wyse oor die "inner monitions" van die Gees insoverre hy die menslike denke buite rekening laat. R.A. Torrey, The person and work of the Holy Spirit, Grand Rapids 1968 (oorspr. 1910) skryf mooi oor die saak, maar vertoon dieselfde eensydigheid.

65. C.J. Jackson, Die Heilige Gees, Pretoria 1978, 109 skryf aanvaarbaar: "Die Gees kan dus ook lei deur die indrukke wat $\mathrm{Hy}$ in 'n mens se gemoed inwerk om 'n bepaalde ding te doen." W.J.M. Janson, "The guidance of the Spirit", in: The Spirit in Biblical perspective (ed. W.S. Vorster), Unisa 1980, 83-93 beklemtoon dat ons moet toelaat dat die Gees ons lei, maar dat ons baie versigtig daarmee moet omgaan en moet besef dat ons sy leiding nooit as 'n waarborg het nie. Hy is te versigtig vir die direkte leiding van die Gees.

66. Vgl. C.H. Dodd, The meaning of Paul for today, London 1975, 140. 